\title{
COMPARISON OF AGGLUTINATING AND GROWTH INHIBITION ANTIBODIES LEVELS IN SOWS IMMUNIZED WITH TWO EXPERIMENTAL INACTIVATED MONOVALENT VACCINES OF CANICOLA SEROVAR: WHOLE CULTURE WITH ALUMINUM HYDROXIDE AND LIPOPOLYSACCHARIDE SUBUNIT WITH LIPID A
}

\author{
F.R.M. Soto ${ }^{1}$, Á.C.B. Delbem², S.R. Pinheiro ${ }^{2}$, Z.M. Morais ${ }^{2}$, A.P. Gonçales ${ }^{2}$, \\ S.S. de Azevedo ${ }^{2}$, F. Bernardi ${ }^{1}$, I.C. de Almeida ${ }^{3}$, S.A. Vasconcellos ${ }^{2}$
}

${ }^{1}$ Centro de Vigilância Sanitária e Controle de Zoonoses "Tereza Rodrigues de Camargo", Estrada da Vargem do Salto, km 4,5, CEP 18150-000, Ibiúna, SP, Brasil.

\begin{abstract}
It was compared the antibody response of sows immunized with two experimental vaccines produced with L.interrogans, serovar Canicola, strain LO-4, isolated in Brazil.One of the vaccines was the usual bacterin (whole culture inactivated with phenol and adjuvanted with aluminum hydroxide - $\mathrm{WC}-\mathrm{AlOH}_{3}$ ) and the other one was a subunit vaccine produced with a lipopolysaccharide (LPS) fraction extracted from the bacteria outer envelop and with the lipid A, also extracted from the leptospira wall as adjuvant (LPS-MPLA). Experiment was as follows: group 1 ( $n=11)$, not immunized control, group 2, $(\mathrm{n}=11)$ : two immunization with 30 days interval of LPS-MPLA vaccine and group $3(n=11)$ : two immunization with 30 days interval of WC-AlOH3 vaccine All three groups were simultaneously immunized, independently of pregnancy stage. Both agglutinin and neutralizing post vaccination antibodies levels were measured respectively by the microscopic sera agglutination with live antigens test (MAT) and the in vitro leptospira growth inhibition test (GIT). Sera collections were performed each 30 days during four months after the first vaccination. Non vaccinated control group animals presented no agglutinating antibodies against Canicola serovar during the whole experiment. At 32 and 68 post vaccination days the agglutinating antibodies levels of group 2 (LPS-MPLA) were significantly higher than the observed in group $3\left(\mathrm{WC} \mathrm{AlOH}_{3}\right)$, respectively, $\mathrm{p}=0.013$ and $\mathrm{p}=0.031$. The differences observed in the growth inhibition antibodies titers of the two vaccines tested were not significant $(p>0.05)$. Despite the peak of post-vaccination agglutinins have been registered at 68 days after first immunization, higher levels growth inhibition antibodies were detected at 30 days of first vaccination. Subunit vaccine presented the same immunogenic capacity for the production of neutralizing antibodies as the whole culture one.
\end{abstract}

KEY WORDS: Swine, leptospirosis, vaccine, active immune response, lipopolysaccharide LPS vaccine, whole culture vaccine.

\section{RESUMO}

COMPARAÇÃO DOS NÍVEIS DE ANTICORPOS PÓS-VACINAIS, AGLUTINANTES E INIBIDORES DO CRESCIMENTO DE LEPTOSPIRAS EM FÊMEAS SUÍNAS IMUNIZADAS COM DUAS VACINAS INATIVADAS EXPERIMENTAIS MONOVALENTES DO SOROVAR CANICOLA: CULTIVOTOTAL INATIVADO COMHIDRÓXIDO DE ALUMÍNIO ESUBUNIDADE DE LIPOPOLISSACARÍDIOS COM MONOFOSFORIL LIPÍDIO A. Foi comparada a resposta imune de fêmeas suínas adultas imunizadas contra a leptospirose, com vacinas monovalentes produzidas com L.interrogans, sorovar Canicola estirpe LO4, isolada no Brasil. A vacina foi empregada em duas formas: cultura de bactérias totais inativada e acrescida do adjuvante de hidróxido de alumínio $\left(\mathrm{WC}-\mathrm{AlOH}_{3}\right)$ e a do tipo de subunidade constituída apenas por uma fração de lipopolisacarídios (LPS) extraídos do envelope externo da bactéria tendo como adjuvante o monofosforil lipídio A, também extraído da parede da leptospira (LPS-MPLA). O delineamento experimental incluiu: grupo $1(n=11)$ : controle não imunizado; grupo $2(n=11)$ : imunizado com duas aplicações em intervalo de 30 dias da vacina LPS MFLA; Grupo $3(n=11)$ : imunizado com duas aplicações em

${ }^{2}$ Universidade de São Paulo, Faculdade de Medicina Veterinária Zootecnia, Departamento de Medicina Veterinária Preventiva e Saúde Animal, Brasil.

${ }^{3}$ Universidade de São Paulo, nstituto de Ciências Biomédicas, Departamento de Parasitologia, São Paulo, Brasil. 
intervalo de 30 dias da vacina $\mathrm{WC}-\mathrm{AlOH}_{3}$. Todos os grupos foram imunizados simultaneamente sem ser considerado o estágio de gestação dos animais. Os níveis de anticorpos pós-vacinais, aglutinantes e neutralizantes foram avaliados, respectivamente, pelos testes de soroaglutinação microscópica com antígenos vivos (SAM) e o de inibição do crescimento de leptospiras in vitro (ICLIV). O monitoramento sorológico foi efetuado a cada 30 dias durante quatro meses após aplicação da primeira dose da vacina. Os animais do grupo controle, não vacinados, não apresentaram anticorpos aglutinantes para o sorovar Canicola durante todo o período experimental. Aos 32 e 68 dias da primo-vacinação, os níveis de anticorpos aglutinantes do grupo 2 (LPS-MPLA) foram significativamente superiores aos observados no grupo $3\left(\mathrm{WC}_{\mathrm{AlOH}}\right)$, respectivamente $\mathrm{p}=0,013$ e $\mathrm{p}=0,031$. As diferenças observadas nos níveis de anticorpos inibidores do crescimento de leptospiras in vitro, induzidos pelas duas vacinas, não foram significativas ( $p>0,05)$. A despeito do pico de anticorpos aglutinantes pós-vacinais ter sido registrado aos 68 dias da primeira imunização, os níveis mais elevados de anticorpos inibidores do crescimento de leptospiras já foram observados aos 30 dias da primo-vacinação. A vacina de subunidade apresentou a mesma capacidade de indução de anticorpos neutralizantes que a vacina de bactérias totais.

PALAVRAS-CHAVE: Suíno, leptospirose, vacinas, resposta imune ativa, lipopolissacarídio, vacina LPS e vacina bactéria total.

\section{INTRODUCTION}

Vaccines used in swine leptospirosis control are inactivated cultures of Pomona, Icterohaemorrhagiae, Hardjo, Canicola, Grippotyphosa and Bratislava serovars. However, these bacterins do notinducecross protectionagainst different pathogenic leptospira serogroups. Usually these vaccines protect only againstclinical illness, butdonotimpair thekidney infection (BRANGEr et al., 2005).

Leptospira subunit vaccines could be an option for the prevention of leptospirosis, since they are usually constituted by antigens that can stimulate immune response, such as lipopolysaccharide (LPS) and its glycolipids, lipoproteins, membrane proteins, phospholipids and peptidoglycan (Cinco et al., 1996).

Midwintwer et al. (1990) detected immune response in hamsters using Pomona and Hardjo LPSderived immunoconjugates anti-leptospira vaccines, with the maximal production of agglutinin titers between the sixth and tenth post vaccination weeks. SONRIERetal.(2000)observed completeprotectionagainst homologous serovars and partial protectionagainstheterologous ones in hamsters treated with leptospira LPS.

Koizumi; Watanabe (2004) developed an anti-leptospira vaccine by the identification of two homologous immunogenic lipoproteins, the Lig A and Lig B, obtained from Leptospira interrogans serovar Manilae, strain UP- MMC- NIID.

In this paper it was compared the antibodies profile induced in sows by two experimental anti-leptospira vaccines, a LPS subunit with lipid A (LPS-MPLA) and a whole culture with aluminum hydroxide $\left(\mathrm{WC}-\mathrm{AlOH}_{3}\right)$. The vaccines were produced with a L. interrogans, serovar Canicola, strain LO-4 isolated in Brazil and It was performed the comparison of agglutinating and growth inhibition antibodies titers during a period of 123 days after the first vaccination.

\section{MATERIAL AND METHODS}

The experiment approved by the Bioethic Commission of the Faculdade de Medicina Veterinária Zootecnia of Universidade deSão Paulo, Brazil was performed in a swine commercial breeding herd with 180 sows at Ibiúna Municipality, São Paulo State, Brazil, during four months from December 2005 to April 2006.

\section{Animals and management conditions}

Thirty three cross bred sows (Sus scrofa), Landrace (LD) $x$ Large White, (LW), aging from 210 to 783 days old, at first to fourth parturition, which have never been vaccinated againstleptospirosis and characterized as not reagent in the microscopic agglutination test (MAT) with 24 strains, were selected from the herd. Animals were submitted toclinical examinationfor the control of body condition and absence of injuries and their clinical history was obtained from the individual files of the pig farm. The animals were maintained in a pen with three meters high and 1 swine $/ 2.5 \mathrm{~m}^{2}$. Each sow was daily fed with $2.2 \mathrm{~kg}$ of commercial swine food divided in two meals. Water was ad libitum in an automatic drinking system. The risk of a leptospira infection was prevented with adequate liquid waste destination, rodent control, daily hygiene practices, disinfection with quaternary ammonium compounds and serological surveillance of the not vaccinated control group of with the MAT with 24 leptospira strains every month during the whole experiment.

\section{Leptospira strain used for vaccine preparation}

The vaccines were produced with a L. interrogans serovar Canicola, strain LO-4 isolated from the liver of a swine killed in a slaughterhouse of Paraná State, Brazil (FreItAs et al., 2004,) and typed with 
monoclonal antibodies in the Royal Tropical Institute, Amsterdam, Netherlands. This strain is pathogenic for hamsters.

\section{LPS and MPLA extraction}

The LPS extraction was performed as follows: a seven to ten days old culture of L. interrogans serovar Canicola strain LO4, 7 to $9 \times 10^{8}$ leptospira/mL was inactivated with thimerosal, centrifuged at $12,000 \mathrm{~g}$, during 20minutes, lyophilized into a pellet and submitted to LPS extraction with chloroform and methanol (2:1) three times (F1a); chloroform and methanol (1:1) four times (F1b); chloroform and methanol (1:2) four times (F1c) and chloroform/methanol/water (10:20:8) fourtimes(F1d), butanolic partition(F3); butanol/water (1:1) water phase (F3a); butanolic phase (F3b) followed by constant shaking during four hours and centrifuged at 1,500xg. The LPS was collected in six fractions: F1a, F1b, F1c, F1d, F3a and F3b according to the chloroform and methanol proportions and using a chromatographic purification and hidrofobic interation in a OctylSepharose column (AlmEIDA et al., 1994; AlmEIDA et al., 2000; AlmEIDA et al., 2003). The immunological reactivity of the fractions was evaluated with a in house capture ELISA test using a polyclonal rabbit antisera against serovar Canicola produced by the Bundesinstitut für Gesundheitlichen Verbraucherschutz und Veterinäermedizin, Berlin, Germany. The fraction F1d obtained with the proportions of $\mathrm{CHCl}_{3}: \mathrm{MetOH}: \mathrm{H}_{2} \mathrm{O}$ $(10: 20: 8)$ presented the highest titers in the ELISA test and was chosen for immunization. The lipid A, monophosforil A lipid (MPLA) was obtained by acid hydrolysis of the same F1d fraction (AlmEIDA et al., 2003; CAMPOS et al., 2004).

\section{LPS subunit vaccine (LPS- MPLA)}

The LPS subunit vaccine was produced with LPS (F1d) fraction at a $2.4 \mathrm{nmol}$ concentration of inorganic phosphate/ $\mu \mathrm{L}$ and MPLA $1.0 \mathrm{nmol}(0.28$ nmol of inorganic phosphate $/ \mu \mathrm{L}$ ).

\section{Thewholecultureinactivated vaccine ( $\left.\mathrm{WC}-\mathrm{AlOH}_{3}\right)$}

The whole bacteria vaccine was produced by the cultivation of leptospiras in EMJH medium (DIFCO) with incubation during seven days at $28^{\circ}$ Celsius. Subcultures were performed each seven days until it was obtained a proper volume with the concentration of 7 to $9 \times 10^{8}$ leptospira/ mL. Culture was inactivated with thimerosal, $0.5 \%(\mathrm{v} / \mathrm{v})$ and phenol $37 \%$, and incubated at $37^{\circ}$ Celsius during two days. The concentration of leptospiras was obtained bycountinginaPetroff-Haussechamber. The cultures were centrifuged at $3.500 \mathrm{~g}$ during two hours at $4^{\circ}$ Celsius. The pellet was resuspended in PBS in the same volume of the initial culture volume and centrifuged at the same conditions. The second pellet was resuspended in PBS at the proportion of $1 / 5$ of the initial volume and the amount of leptospiras was evaluated achieving the level of $10^{8}$ leptospiras $/ \mathrm{mL}$. The final composition of the vaccine in one milliliter was $10^{8}$ leptospiras, Aluminum hydroxide $0,15 \%$ final concentration, thimerosal $0.01 \%$, final concentration and PBS (MAsuZAWA et al., 1991).

\section{Swine vaccination and blood collections}

The experiment was done with three groups of 11 animals receiving the first vaccination or saline solution without considering the pregnancy phase.

Group 1: control, received two doses of saline solution with 30 days interval.

Group 2: received two doses of the LPS-MPLA L. interrogans serovar Canicola strain L0-4 vaccine with 30 days interval.

Group 3: received two doses of $\mathrm{WC}-\mathrm{AlOH}_{3} \mathrm{~L}$. interrogans serovar Canicola, strain LO-4, whole culture bacterin with 30 days interval.

Vaccines and saline solution were injected subcutaneously at the ear of the animals in a volume of $1.0 \mathrm{~mL}$ per animal, at the first vaccination and 2.0 $\mathrm{mL}$ at the booster dose.

Blood collection was performed aseptically with disposable needles (size 40 X12) by cranial cava vein punction each 30 days during four months after first vaccination.

\section{Serological tests}

MAT test for the measurement of agglutinin antibodiestiterswasperformed withthemicrotechnique of microscopic agglutination test, Cole etal. (1973) and GALTON et al. (1965). Live cultures in modified EMJH medium (ALVES et al., 1996) with four to eight days of culture, $1 / 2$ of Mac Farland scale turbidity. Twenty two pathogenic leptospira strains and two avirulent ones were used: Australis, Bratislava, Autumnalis, Butembo, Castellonis, Bataviae, Canicola, Whitcombi, Cynopteri, Sentot, Grippotyphosa, Hebdomadis, Copenhageni, Icterohaemorrhagiae, Panama, Pomona, Pyrogenes, Wolffi, Hardjo, Shermani, Tarassovi, Javanica, Andamana and Patoc. Sera were diluted at 1:50 in PBS and tested against the whole collection of live antigens. The final dilution of antigen-sera mixture was 1:100 and considered as the cut off point of the reaction. Positive sera in the trial phase were titrated in two fold dilution series with the respective reactive serovars. The titer was the reciprocal of the highest sera dilution presenting $50 \%$ of leptospiras agglutinated under dark field microscopy.

Theneutralizing antibodies titers were evaluated with the in vitro leptospira growth inhibition test 
(GIT) (TRIPHATY et al., 1973; TABATA et al., 2002). The procedure was adjusted to the laboratory conditions with leptospiras cultures of four to eight days of age in liquid modified EMJH media (ALVES et al., 1996; TURNER et al., 1970). Serum samples were inactivated in water bath for 30 minutes at $56^{\circ}$ Celsius. Each no contaminated samplewas examined in four dilutions, $(1: 2,1: 4,1: 8$ and 1:16) five tubes per dilution. In each tube it was included $2.5 \mathrm{~mL}$ of EMJH modified media (Alves etal., 1996; TurnER etal., 1970), $0.2 \mathrm{~mL}$ of serum dilution and $0.1 \mathrm{~mL}$ of leptospiras culture. The tubes were incubated at 28 to $30^{\circ}$ Celsius during two weeks. After this period it was done the observation of the leptospiras growth. The tubes that presented no turbidity by naked eye observation and less than ten leptospiras by dark field microscopy examination, 120 magnification, were considered positive for inhibition of leptospiras growth. When a serum sample presented contamination it was filtered in swinny Millipore filters $0,22 \mu \mathrm{m}$.

\section{Statistical analysis}

As the variables in study were quantitative and expressed in arithmetic mean, the group size of eleven animals were adopted. The results of swine vaccination were analyzed with the comparison of reagent animal rates and agglutinin and neutralizing antibodies mean titers. The agglutinating antibodies titers were expressed in base 10 logarithm. Value 1 was attributed to non reagent animals, and it was added value 1 to calculate base 10 logarithm for titers of 100, 200,400,800, 1600 and 3200, resulting in $\log 2.004,2.303,2.603,2.904,3.204$ and 3.505, respectively. The growth inhibition antibodies titers were calculated by the method of REED; MÜENCH (1938). The comparison of arithmetic means of agglutinating and growth inhibition antibodies titers was performed by Kruskall Wallisnon-parametric tests or U of Mann Whitney, when indicated, using SPSS, 12.0 version program. Significance level was $5 \%$. The GIT titers detected in the control group were considered unspecific and arithmetic mean of this group was subtracted from results of the vaccinated ones. Confidence intervals (95\%) of growth inhibition antibodies were calculated according to PIzzI (1950).

\section{RESULTS}

\section{Agglutinating antibodies}

On the 32nd post vaccination day the proportion of reactant animals immunized with the $\mathrm{WC}-\mathrm{AlOH}_{3}$ vaccine was $0 / 11$ and to the LPS-MPLA vaccine it was 6/11, with an arithmetic mean titer of 0.91 and titer standard error of 1.047. On the 68th post vaccination day with the $\mathrm{WC}-\mathrm{AlOH}_{3}$ vaccine the proportion of reactant animals was $8 / 11$, with the arithmetic mean titer of 1.144 and standard error of 1.438 but to the LPS-MPLA vaccine at the same day the results were respectively 11/11, 2.303 and 0.134 . On the 94th post vaccination day with the $\mathrm{WC}-\mathrm{AlOH}_{3}$ vaccine the proportion of MAT reactant animals was 2/10, with an arithmetic mean titer of 0.230 and standard error of 0.728 , with the LPS-MPLA vaccine, at the same day, the results were respectively $3 / 11,0.446$ and 0.995 . On the $123 \mathrm{rd}$ post vaccination day with WC- $\mathrm{AlOH}_{3}$ vaccine the proportion of MAT reactant animals was $3 / 9$, with an arithmetic mean titer of 0.479 and standard error of 0.953 , with LPS-MPLA vaccine, at the same day, the results were respectively $2 / 7,0.286,0.757$.

Figure 1 shows the results of MAT tests for groups 2 and 3 of vaccinated sows and time of blood collection. There were a higher production of agglutinating antibodies titers after 68 days of first vaccination $(p=0.035)$ in group 2, vaccinated with LPS- MPLA vaccine. The animals of group one remained as not reagents in the five performed evaluations.

Arithmetic means for LO-4 strain Canicola serovar agglutinin titers from sows immunized with LPS-MPLA subunit vaccine were higher than those observed for $\mathrm{WC}-\mathrm{AlOH}_{3}$ vaccine: $\mathrm{p}=0.013$ and $p=0.031$, respectively, for days 32 and 68 after first vaccination. On the other blood collections the observed differences were not significant $(\mathrm{p}>0.05)$.

\section{Neutralizing antibodies}

The arithmetic median titer and standard error observed in the no vaccinated group was 0.113 , so the value was always subtracted from the results obtained in the vaccinated groups.

On the 32nd post vaccination day with the WC$\mathrm{AlOH}_{3} \mathrm{vaccine}$ the proportion of reactor animals was $7 / 11$, with arithmetic mean titer and $95 \%$ confidence interval of $0.329 \pm 0.017$, but with the LPS-MPLA vaccine the obtained results were respectively $5 / 11$ and $0.175 \pm 0.021$. On the 68 th post vaccination day with $\mathrm{WC}-\mathrm{AlOH}_{3}$ vaccine the proportion of reactor animals was $6 / 10$, with arithmetic mean titer and $95 \%$ confidence interval of $0.118 \pm 0.093$ as with the LPS-MPLA vaccine the results were respectively $9 / 11$ and $0.194 \pm 0.063$. On the 94 th post vaccination day with $\mathrm{WC}-\mathrm{AlOH}_{3}$ vaccine the proportion of reactor animals was $6 / 10$, with arithmetic mean titer and $95 \%$ confidence interval of $0.042 \pm 0.043$ as with the LPS-MPLA vaccine the results were respectively $4 / 11$ and $0.035 \pm 0.036$. On the 123 rd post vaccination day with WC-AlOH3 vaccine the proportion of reactor animals was $1 / 10$, with arithmetic mean titer and $95 \%$ confidence interval of $0.061 \pm 0,000$ but with 
LPS-MPLA vaccine the results were, respectively, $4 / 10$ and $0.200 \pm 0.061$.

Results of the GIT in groups 2 and 3 at the moment of each blood collection are presented in Figure 2. In the blood collections performed at 68 and 123 days, the differences observed between the LPS-MPLA subunit vaccine and the WC-AlOH $\mathrm{H}_{3}$ were not significant $(\mathrm{p}>0.05)$.

\section{DISCUSSION}

The agglutinating antibodies levels of group 2 , at 32nd and 68th post vaccination days were significantly higher than the respectively observed in group 3. MidWINTWER et al. (1990) also found immunological responsein hamstersimmunized with anti-leptospira LPS bivalent vaccine serovars Pomona and Hardjo with agglutinin titers peaks at 42 and 70 days after vaccine application. SONRIER et al. (2000) observed that hamsters immunized with leptospira LPS presented peaks of agglutinating antibodies after the booster dose and neutralizing antibodies during a period of 120 days post vaccination.

In the present work, at 94th days from the first vaccination, there was a strong agglutinin titer reduction either for the subunit vaccine as well as for the whole culture one. This short vaccine response period, mediated by the brevity of the presence of agglutinating antibodies were also reported in cattle by CACCHIONE et al. (1969) and in water buffaloes by NARDI et al. (2007).

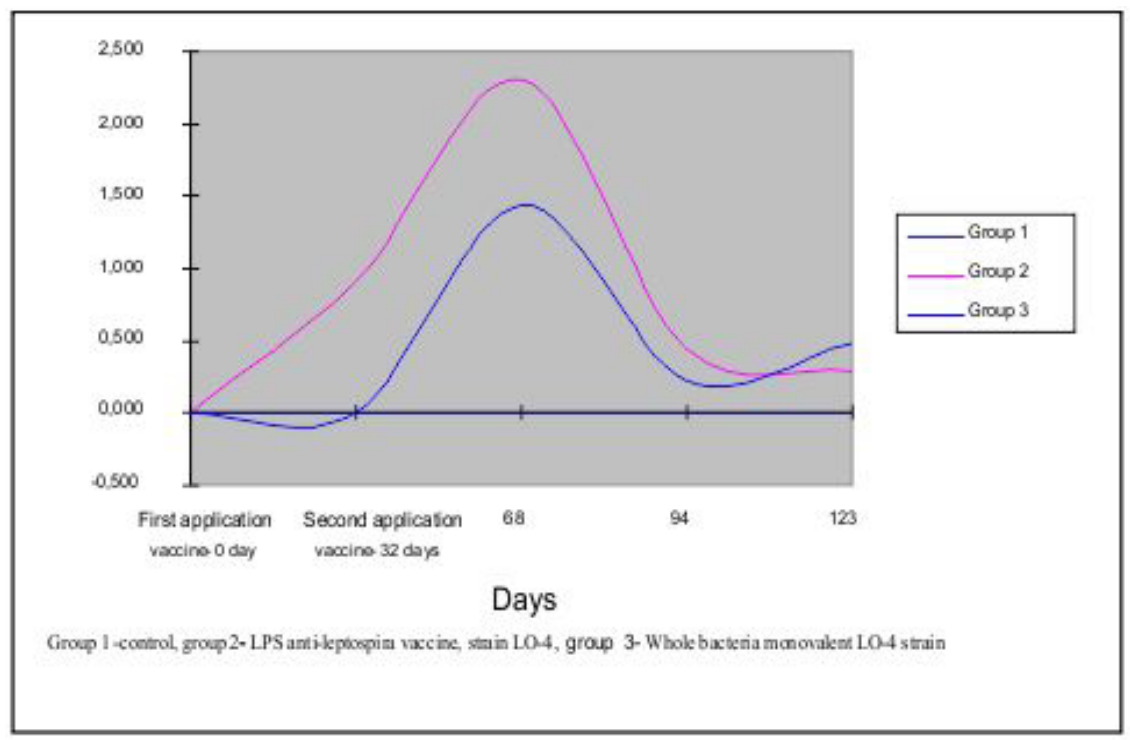

Fig. 1 - Arithmetic means of agglutinating antibody titers expressed in logarithm base 10 to sample LO-4 serovar Canicola in sows with experimental vaccines produced with the same sample, in relation to the group and the time expressed in days after first vaccination.

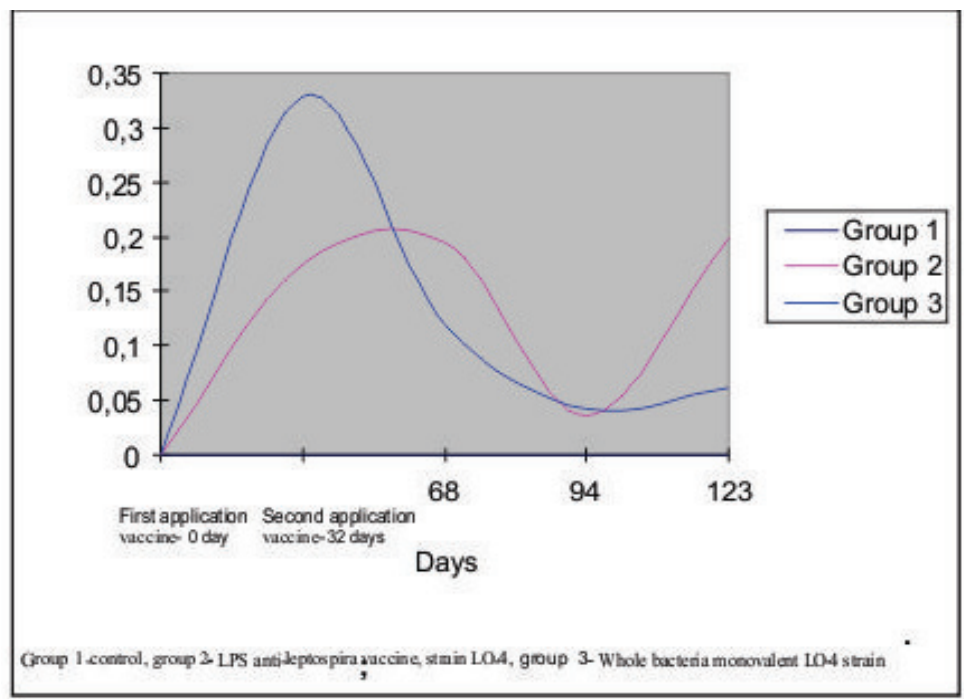

Fig. 2 - Arithmetic means of neutralizing antibody titers expressed in logarithm base 10 to sample LO-4 serovar Canicola in sows with experimental vaccines produced with the same sample, in relation to the group and the time expressed in days after first vaccination. 
In the present investigation, in swine immunized against leptospirosis the post vaccination in vitro GIT antibodies presented no correlation with the agglutinating ones. The same was observed by NARDI et al. (2007) in water buffaloes.

In spite of the observation of a strong GIT antibodies decrease at the 94 th post first vaccination day for both tested vaccines, it is probable that a longer persistence of these antibodies could be achieved if it was used higher vaccine doses. In bovines vaccinated with anti-leptospirosis whole culture vaccine it was observed that the level of post-vaccine agglutinins is dependent of the antigen concentration in the vaccine (FÁVERO et al., 1997).

The results presented in Figure 2, showed that the booster vaccination with both vaccines tested, at thirty days from the first vaccination did not promote an increase in the GIT antibodies levels. It seems even that there was a decrease of these antibodies just after the second vaccination. It is probable that this condition could be caused by the antibody consumption due to the vaccine antigen. This possibility was analyzed and discussed in rabies prophylaxis (ITOe al., 1991; Morse etal., 1958). On the 123rd day after the first vaccination it was observed an increase in the GIT antibodies induced mainly by the LPS-MPLA vaccine, but this difference was not significant $(p>0.05)$.

\section{ACNOWLEDGEMENTS}

The authors thank Dr. Igor Correa for the valuable cooperation for the experimental LPS vaccine production (extraction and purifying phases).

\section{REFERENCES}

ALMEIDA, I.C.; FERGUSON, M.A.J.; SCHENKAMAN, S.; TRAVASSOS, L.R. Lytic anti-alpha- galactosyl antibodies from patients with chronic Chagas' disease recognize novel O- linked oligosaccharides on mucin-like glcosyl-phosphatidylinositol-anchored glycoproteins of Trypanosoma cruzi are potent proinflammatory agents. Biochemical Journal, v.304, p.793-802, 1994.

ALMEIDA, I.C.; PROCÓPIO, D.O.; SILVA, L.S.; MEHLERT, A.; TRAVASSOS, L.R., GAZZINELLI, R.T.; FERGUSON M.A. Highly purified glycosylphosphatidylinositols from Trypanosoma cruzi are potent proinflammatory agents. EMBO Journal, v.19, p.1476-1485, 2000.

ALMEIDA, I.C.; TRAVASSOS, L.R.; RAW, I. A simple method for the preparation of Lipid A from Gram- negative bacteria and its application as adjuvant in vaccination. Instituto Nacional de Propriedade Industrial (INPI). Patent application. 2003.

ALVES, C.J.; VASCONCELLOS, S.A.; CAMARGO, C.R.A.; MORAIS, Z.M. Influência de fatores ambientais na proporção de caprinos soro-reagentes para a leptospirose em cinco centros de criação do Estado da Paraíba. Arquivos do Instituto Biológico, São Paulo, v.63, n.2, p.11-18, 1996.

BRANGER, C.; CHATRERRET, B.; GAUVRIT, A.; AVIAT, F.; AUBERT, A.; BACH, J.M.; FONTAINE, G.A Protection against Leptospira interrogans Sensu Lato, Challenge by DNA Immunization with the Gene Encoding Hemolysin - Associated Protein 1. Infection and Immunity, v.73, p.4062-4069, 2005.

CACCHIONE, R.A.; FUENTE, A.; CASCELLI, E.S.; MARTINEZ E.S. Inmunidad pasiva antileptospira en bovinos lactantes e inmunidad activa del destete. Revista de Investigacínes Agropecuarias, v.11, p.112-120, 1969.

CAMPOS, M.A.; ROSINHA, G.M.S.; ALMEIDA, I.C.; SALGUEIRO, X.S.; JARVIS, B.W.; SPLITTER, G.A.; QURESHI, N.; BRUNA-ROMERO, O.; GAZZINELLI, R.T.; OLIVEIRA, S.C. Role of toll like receptor 4 in inductions of cell-mediated immunity and resistance to Brucella abortus infection in mice. Infection and Immunity, v. 72, n.1, p. 176186, 2004.

CINCO, M.; VECILE, E.; MURGIA, R.; DOBRINA, P.; DOBRINA, A. Leptospira interrogans and Leptospira peptidoglycans induce the release of tumor necrosis actor $\infty$ from human monocytes. FEMS Microbiology, v.138, p.211-214, 1996.

COLE, J.R.; SULZER, C.R.; PULSSELY, P.R. Improved microtechnique for the leptospiral microscopic agglutination. Journal of Applied Microbiology, v.6, p.976-980, 1973.

FAVERO, A.C.M.; MANGERONA, A.C.S.; ALESSI, L.J.; MORAIS, Z.M.; PINHEIRO, S.R.; FERREIRA NETO, J.S.; VASCONCELLOS, S.A. Aglutininas pós-vacinais em bovinos imunizados com bacterina tetravalente contra a leptospirose. Influência de reações pré-vacinais, homólogas e heterólogas. Arquivos do Instituto Biológico, São Paulo, v.64, n.2, p.45-55, 1997.

FREITAS, J.C.; SILVA, F.G.; OLIVEIRA, R.C.; DELBEM, A.C.B.; MÜLLER, E.E.; ALVES, L.A.; TELES, P.S. Isolation of Leptospira spp. from dogs, bovine and swine naturally infected. Ciência Rural, v.34, p.853-856, 2004.

GALTON, M.M.; SULZER, C.R.; SANTA ROSA, C.A.; FIELDS, M. J. Application of a microtechnique to the agglutination test for leptospiral antibodies. Journal of Applied Microbiology, v.1, p.81-85, 1965.

ITO, F.H.; CÔRTES, J.A.; RWEYEMAMU, M.M.; UMEHARA, O.; MEDEIROS NETO, R.R.; LUCCA 
NETO, D.; BALTAZAR, M.; VASCONCELLOS, S.A.; VASCONCELLOS, M.E.R. Course of secondary immune response shortly after revaccination with BHK-21 cell culture inactivated rabies vaccine adjuvanted with aluminum hydroxide. Brazilian Journal of Veterinary Research and Animal Science, v.28, n.1., p.51-57, 1991.

KOIZUMI, N.; WATANABE, H. Leptospiral immunoglobulin- like protein elicit protective immunity. Vaccine, v.22, p.1545-1552, 2004.

MASUZAWA, T.; SUZUKI, R.; YANAGIHARA, Y. Comparison of protective effects with tetravalent glycolipid antigens and whole cell-inactivates vaccine in experimental infection of Leptospira. Microbiology and Immunology, v.35, p.199-208, 1991.

MIDWINTER A.; FAINE S.; ADLER, B. Vaccination of mice with lipopolysaccharide (LPS) and LPS-derived immuno-conjugates from Leptospira interrogans. Journal of Medical Microbiology, v.3, p.199-204, 1990.

MORSE, E.V.; BAUER, D.C.; LANGHAN, R.F.; LANG, R.W.; ULLREY, D.E. Experimental Leptospirosis IV. Pathogenesis of porcine Leptospira pomona infections. American Journal of Veterinary Research, v.19, p.388, 1958.

NARDI, J.G.; GENOVEZ, M.E.; RIBEIRO, M.G.; CASTRO, V.; JORGE, A.M. Interference of vaccinal antibodies on serological diagnosis of leptospirosis in vaccinated buffalo using two types of commercial vaccines. Brazilian Journal of Microbiology, v.38, p.363-368, 2007.
PIZZI, M. Sampling variation of the fifty percent end-point, determined by Reed-Muench (Behrens) method. Human Biology, v.3, p.151-190, 1950.

REED, L.J.; MUENCH, H. A simple method of estimating fifty percent endpoints. American Journal of Hygiene, v.27, p.493-497, 1938 .

SONRIER, C.; BRANGER, C.; NICHEL, V.; RUVOËN, J.P.; GANIÉRE, G.; FONTAINE A. Evidence of cross- protection within Leptospira interrogans in an experimental model. Vaccine, v.1, p.89-94, 2000.

TABATA, R.; SCANAVINI NETO, H.; ZUANAZE, M.A.F.; OLIVEIRA, E.M.D.; DIAS, R.A.; MORAIS, Z.M.; ITO, F.H.; VASCONCELLOS, S.A. Cross neutralizing antibodies in hamsters vaccinated with leptospiral bacterins produced with three serovars of serogroup sejroe. Brazilian Journal of Microbiology, v.33, p.267-270, 2002.

TRIPHATY, D.N.; HANSON, L.E.; MANSFIELD, M.E. Growth inhibition test for measurement of immune response of animals vaccinated with leptospiral bacterins. In: ANNUAL MEETING, UNITED STATES ANIMAL HEALTH ASSOCIATION, 77., 1973, Missouri. Proceedings. Missouri, 1973.

TURNER, L.H. Leptospirosis III. Maintenance, isolation and demonstration of leptospires. Transactions of the Royal Society of Tropical Medicine and Hygiene, v.64, p.623-646, 1970.

Received on $1 / 2 / 10$

Accepted on 2/2/11 